\title{
Natural gas supplies as an instrument of geopolitical conflict between the Russian Federation and Ukraine
}

ABSTRACT: The natural gas supply is used from Russia Federation as a political instrument in the geopolitical and territorial conflict with Ukraine. The effectiveness of Russian strategy towards Ukraine is due to the fact that power in Kiev is also exercised by the pro-Russian politicians and supported on the part of Ukrainian oligarchs. The two countries are interdependent in terms of energy by means of the existing gas infrastructure and long-term contracts, because Ukraine guarantees the Russian Federation the transit of natural gas to Europe through its system of transmission gas pipelines, and Russia pays for the transit and used to supply the agreed amount of gas to Ukraine. For the first time - in 2016 - Ukraine didn't import natural gas directly from the Russia Federation. This article attempts to obtain an answer to the research question, whether Ukraine actually strives to diversify its natural gas supply. What part of this policy is the Ukrainian political instrument in terms of Russia, and what part is the real political objective? Especially in the context of the gas contract between both States, ending in 2019. What role will be played the underground gas storage in the geopolitical struggle? Despite Nord Stream II the Russian Federation still needs the Ukrainian pipelines to fulfill contractual obligations in gas supplies to Europe. What are the strategic goals of the energy policy of Ukraine and Russia? The geopolitical as well as geo-economic theories will be applied. Moreover, a factor analysis as well as a decision-making analysis will be used.

$\triangle$ Corresponding Author: Mariusz Ruszel; e-mail: mruszel@prz.edu.pl

1 Department of Economics of the Faculty of Management, Rzeszow University of Technology, Poland; ORCID iD: 0000-0003-1546-6754; e-mail: mruszel@prz.edu.pl

2019. The Author(s). This is an open-access article distributed under the terms of the Creative Commons Attribution-ShareAlike International License (CC BY-SA 4.0, http://creativecommons.org/licenses/by-sa/4.0/), which permits use, distribution, and reproduction in any medium, provided that the Article is properly cited. 
The political analysis method and the forecasting technique are applied to obtain, not only theoretical, but also practical input.

KEYWORDS: natural gas, pipelines, geopolitics, Ukraine, Russia Federation

\section{Introduction}

Natural gas is an energy resource of strategic importance for a country's energy security and the competitiveness of its economy (Ruszel 2014). Disturbing the continuity of the supply of this resource may lead to a loss of people's trust in current authorities, financial losses for energy-intensive industry, and in an extreme situation, the loss of political power in the country. In political science it is acknowledged that natural gas supplies may be used as an instrument of political pressure on other decision-making centers. Research analysis of the Russian energy policy confirms that Gazprom has repeatedly used natural gas supplies to Ukraine in an instrumental way (Grabau 2018; Goldthau and Boersma 2014; Fedorov 2013). Daniel Yergin stresses that withholding Russian gas supplies to Europe in 2006 as a result of the crisis between Russia and Ukraine was a shock for EU leaders (Yergin 2012). The gas crisis between Russia and Ukraine occurred again in 2009 (Bettzüge and Lochner 2009; Ruszel 2015). The two countries are interdependent in terms of energy by means of the existing gas infrastructure and long-term contracts (Ascari 2011), because Ukraine guarantees the Russian Federation the transit of natural gas to Europe through its system of transmission gas pipelines, and Russia pays for the transit and used to supply the agreed amount of gas to Ukraine. However, at present, both countries are trying to become more independent and are applying active diversification policies. In the case of Russia, this includes the construction of Nord Stream II and Turkish Stream, and in the case of Ukraine, te diversification of sources and directions of natural gas supply. This article attempts to obtain an answer to the research question whether Ukraine is actually striving to diversify its natural gas supply. What part of this policy is the Ukrainian political instrument regarding Russia, and what is the real political objective? Especially in the context of the ending of gas contract between both states in 2019 . What role will be played by underground gas storage in the geopolitical struggle? Despite Nord Stream II, the Russian Federation still needs the Ukrainian pipelines to fulfill its contractual obligations in gas supplies to Europe. What are the strategic goals of the energy policy of Ukraine and Russia? Geopolitical and geo-economic theories will be applied in the work in order to answer the questions. Moreover, a factor analysis as well as a decision-making analysis will be used. The political analysis method and the forecasting technique are applied to obtain, not only theoretical, but also practical input. 


\section{Theoretical framework}

The problem discussed of the article is approached from the perspective of the theory of international relations. The main study subject is countries, and the study object - their political interests, which is reflected in the theory of realism (Morgenthau 1956; Niebuhr 1960; Carr 2001). Representatives of this theoretical school emphasize the importance of the instruments of pressure and power in international relations (Loś-Nowak 2000), which may take the form of i.a., energy blackmail or withholding natural gas supplies. The theory of complex interdependence, formulated by Robert Koehane and Joseph Ney, was applied in the article (Keohane and Nye 1977). From the theoretical perspective, interdependence is a situation in which different countries or actors from different countries have a mutual influence on each other (Rana 2015). The authors of this theoretical concept point out that increasing the importance of economy and the development of other forms of political interdependence are currently becoming a strategic political instrument. This theoretical model assumes that each actor has different needs, capabilities and priorities in foreign policy (Koehane and Nye 1997). The concept includes three aspects connected with interdependence: a) the multiplicity of channels connecting communities, which involve various formal and informal connections between authorities, elites and transnational corporations; b) the lack of hierarchy of issues that are the subject of relationships between the countries, as well as blurred division into internal and foreign policy; c) no military force is used in the situation of complex interdependence (Keohane and Nye 1977). It is also stressed that non-state actors, whose goals and policies may differ from those of the mother country, are playing a more and more important role. Apart from this theoretical concept, the article reflects the approach by Kenneth Waltz, who emphasized that the contemporary competition between countries takes place in the economic and technological sphere (Waltz 1993). Edward Luttwak points out that the relationships between politics and the economy are crucial in terms of understanding any country's power and strength. Therefore, he argues in his texts that a country's policy is based on gaining advantage over another country through instruments and measures other than force (Luttwak 1990). The subject of discussion in this article is Ukraine and the Russian Federation with their complex interdependence with regard to the object of the study: natural gas and energy infrastructure. Political interdependence between Ukraine and the Russian Federation in gas policy produces both costs and benefits for each side. 


\section{Diversification policy from the perspective of Ukraine and the Russian Federation}

In 2017 Ukraine consumed 32 billion $\mathrm{m}^{3}$ of natural gas, of which domestic extraction was about 18 billion $\mathrm{m}^{3}$ and imports 14 billion $\mathrm{m}^{3}$ It should be reminded that at the end of November 2015 Ukraine withheld the import of natural gas from the Russian Federation and decided to purchase this energy source from Western European companies. In 2016 natural gas was supplied to Ukraine by 34 companies, delivering a total of 11.1 billion $\mathrm{m}^{3}$ while in 2017 it was already 67 companies, and the volume of supplies increased by $27 \%$ to $14.1 \mathrm{billion}^{3}$ (Naftogaz Europe 2018). In 2017, over 70\% of imported natural gas to Ukraine was supplied by Slovakia, about $20 \%$ by Hungary and $10 \%$ by Poland. However, in the period January-June 2018 Ukraine purchased 4.18 billion $\mathrm{m}^{3}$ of natural gas, of which companies registered in Switzerland (e.g. Axpo Trading AG) delivered $1.72 \mathrm{bcm}$ of this energy source, the second supplier was Germany with deliveries at level 1, 35 billion $\mathrm{m}^{3}$ while the third is Poland in the amount of 334 million $\mathrm{m}^{3}$. At that time, natural gas was supplied to Ukraine also by: Great Britain (310 million $\mathrm{m}^{3}$ ), Hungary (117 million $\mathrm{m}^{3}$ ), Slovakia ( 89 million $\mathrm{m}^{3}$ ), Luxembourg (57 million $\mathrm{m}^{3}$ ) and Austria (21 million $\mathrm{m}^{3}$ ) (Zaniewicz 2018). However, the Stockholm Arbitration Court Ruling in 2018 requires Naftohaz to purchase of 4 billion $\mathrm{m}^{3}$ of natural gas from Russian Gazprom. This means that the Russian energy source may return to the Ukrainian market as part of the direct deliveries in the nearest future. It cannot be ruled out that Russian gas is also supplied by one of the Swiss companies. On the other hand, in 2017, the Russian Federation sent 93 billion $\mathrm{m}^{3}$ of natural gas to Europe and Turkey via Ukrainian gas transmission pipelines (Stępiński 2018).

For Ukraine, the diversification of gas supplies means purchasing it from a West European company and transferring it via Slovakia, Hungary or Poland. For Russia, diversifying gas exports to Europe involves the need to build new gas infrastructure in the form of Nord Stream II and Turkish Stream. In other words, Ukraine is trying to become independent from Russian gas, and Russia, from Ukrainian gas pipelines. The current interdependence between Russia and Ukraine is based on a gas contract for the supply of gas to Ukraine and a transmission contract. Both contracts are in force until December 31, 2019. Therefore, both sides are negotiating to achieve their own strategic goals. The decisions of the Arbitration Tribunal in Stockholm (Kardaś and Konończuk 2018), which ordered Gazprom to pay Naftogaz USD 4.63 billion in compensation for transferring lower amounts of gas through Ukrainian gas pipelines than contractual obligations, are going to play a very important role. Ukraine is currently sequestering Russian assets on account of Russian financial liabilities. The Tribunal also decided that Ukraine was obliged to accept $4 \mathrm{bcm}$ natural gas a year (Naftogaz 2018). Appeal proceedings may last many months, and legal proceedings will soon be one of the instruments used by both sides in negotiations concerning a new transit connect (Kardaś and Matuszak 2018). 


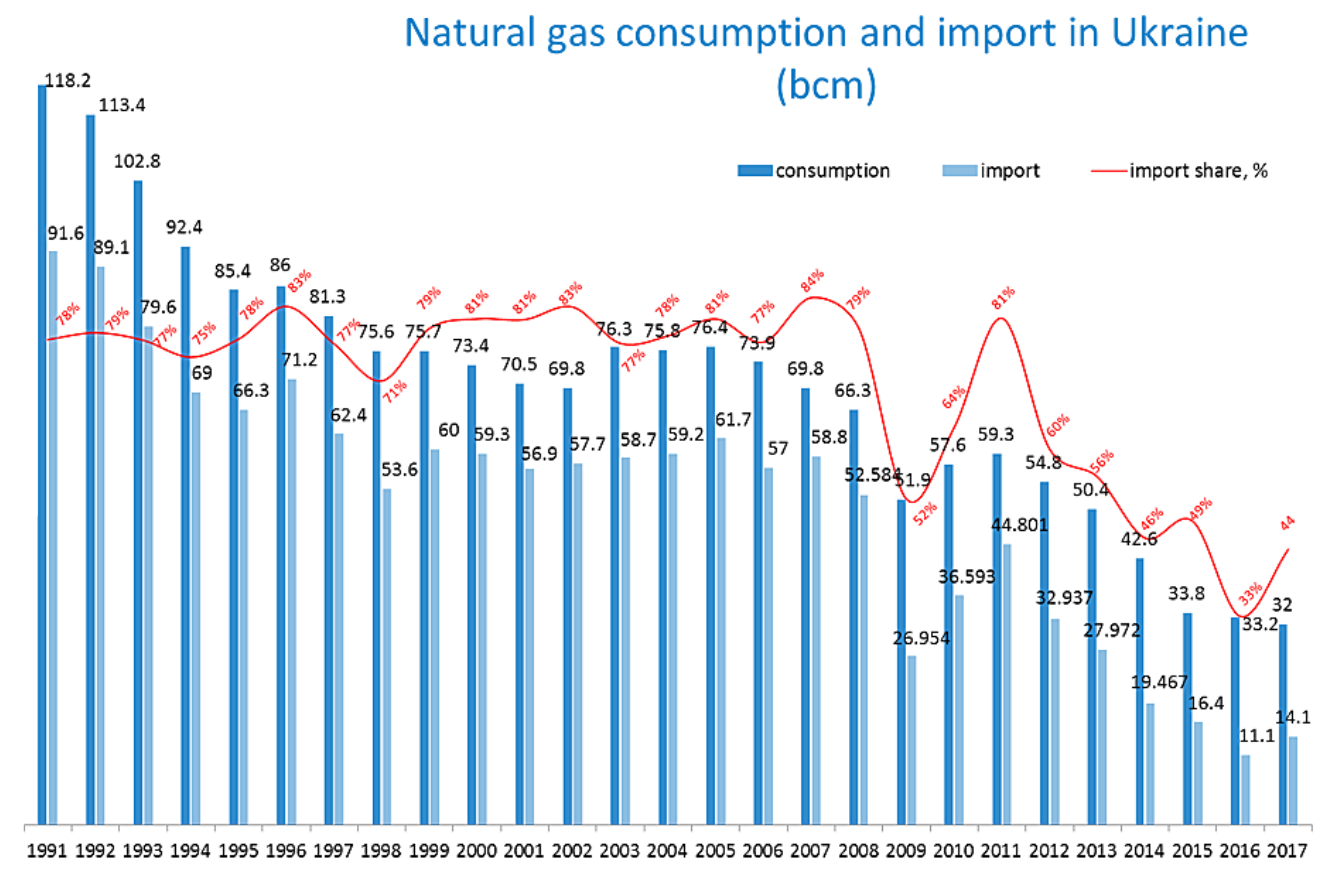

Fig. 1. Consumption and import of natural gas to Ukraine Source: Natural Gas Consumption and Import in Ukraine, https://naftogaz-europe.com/article/en/ naturalgasimportinukraine

Rys. 1. Konsumpcja i import gazu ziemnego na Ukrainę

\section{Importance of underground natural gas storage facilities}

Ukraine has very well developed strategic gas infrastructure, including a system of gas pipelines with the total length of over 36 thousand $\mathrm{km}, 14$ thousand $\mathrm{km}$ of which is high pressure gas pipelines with the diameter of 1,020-1,420 mm (Kardaś and Matuszak 2018). Generally, the transmission capacity of Ukrainian gas pipelines exceeds $290 \mathrm{bcm}$ natural gas at the northern and eastern border, and 130-170 bcm at the southern and western border (Szeptycki 2008). The transmission capacity of natural gas transfer via Ukraine to Europe is currently nearly $140 \mathrm{bcm}$ a year. An important role is played by the: Alliance, Brotherhood and Northern Light gas pipelines, which are used to transport not only Russian gas, but also the one from the Central Asian countries. It reaches to the following countries: Poland, Slovakia, Czech Republic, Austria, Italy, Germany, France, Switzerland, Hungary, Romania, Bulgaria, Turkey, Greece, Macedonia and Moldova (Energy Charter Secretariat 2010). At the moment, almost 20\% of Ukrainian gas pi- 
pelines have been used longer than 45 years, and approx. 15\%, longer than 35 years (Energy Charter Secretariat 2010). In addition, gas losses in the transmission system may amount to $20 \%$ or more (Energy Charter Secretariat 2010)*. Thus, the system of pipelines requires investment expenditure for modernization.

Apart from the system of gas pipelines, Ukraine has the largest natural gas underground storage facilities in Europe. They are of strategic importance, since they ensure the possibility of balancing gas supplies to Europe in periods of increased demand, which usually occurs in winter. Ukraine has a total of 13 natural gas underground storage facilities (see: Table 1) with the capacity of $31 \mathrm{bcm}$ (12 of them are administered by the company Ukrtransgaz) (Ukrtransgaz Today 2018). Ukraine built its underground storage facilities in the years 1964-1988. This means that the oldest elements of this energy infrastructure are now over 50 years old and need to be modernized. Taking the forms of development of natural gas trade in the market into consideration (e.g., virtual reverses, virtual gas hubs), we can see that this kind of energy infrastructure is growing in importance. Roberto Roson and Franz Hubert emphasize that market play is possi-

TABLE 1. Capacity of underground natural gas storage in Ukraine

TABELA 1. Pojemność podziemnych magazynów gazu ziemnego na Ukrainie

\begin{tabular}{|c|l|c|}
\hline No. & \multicolumn{1}{|c|}{ Name of the underground gas storage } & Active capacity (bcm/year) \\
\hline 1. & Biche-Volytsko-Uherskie & $17.05 \mathrm{bcm}$ \\
\hline 2. & Bohorodchanske & $2.3 \mathrm{bcm}$ \\
\hline 3. & Dashavske & $2.15 \mathrm{bcm}$ \\
\hline 4. & Oparskie & $1.92 \mathrm{bcm}$ \\
\hline 5. & Uherskie & $1.9 \mathrm{bcm}$ \\
\hline 6. & Chervono-Partyzanske & $1.5 \mathrm{bcm}$ \\
\hline 7. & Solokhivske & $1.2 \mathrm{bcm}$ \\
\hline 8. & Kehychivske & $0.7 \mathrm{bcm}$ \\
\hline 9. & Hlibivske & $1 \mathrm{bcm}$ \\
\hline 10. & Proletarske & $1 \mathrm{bcm}$ \\
\hline 11. & Krasnopopivske & $0.42 \mathrm{bcm}$ \\
\hline 12. & Verhunske & $0.4 \mathrm{bcm}$ \\
\hline 13. & Oleshivske & $0.31 \mathrm{bcm}$ \\
\hline TOTAL & $\mathbf{1 3}$ storages & $\mathbf{3 0 . 9 5} \mathbf{b c m}$ \\
\hline
\end{tabular}

Source: own study based on data from Naftohaz August 1, 2018, https://naftogaz-europe.com/article/en/englstorage [Accessed: August 8, 2018].

* It is estimated that the average hydraulic efficiency of Ukrainian gas pipelines is about $80 \%$, so nearly $20 \%$ of natural gas is lost at compressor stations. 
ble on the basis of gas infrastructure (Roson and Hubert 2014). More and more companies are deciding to develop the sale of natural gas on the Ukrainian market, which is connected with the need to conclude contracts for using gas networks and storage capacities. EU countries can store their gas in Ukrainian storage facilities, and Ukraine offers Western European companies the storage of almost $14 \mathrm{bcm}$ of gas in the customs warehouse mode (storage for up to 3 years without paying fees or customs duties) (BiznesAlert 2018). This way, energy concerns can invest in gas storage in Ukraine and store it when the price on the market is low and sell it when the price increases. The development of this kind of activity would maintain the cost-effectiveness of the infrastructure and create a gas hub based on the potential of gas storage facilities. Therefore, competition for access to storage facilities may intensify in the future, and interest of Western European concerns may grow. Ukraine would benefit from the establishment of legal regulations that would contribute to the increased attractiveness of this gas infrastructure while retaining the present ownership structure.

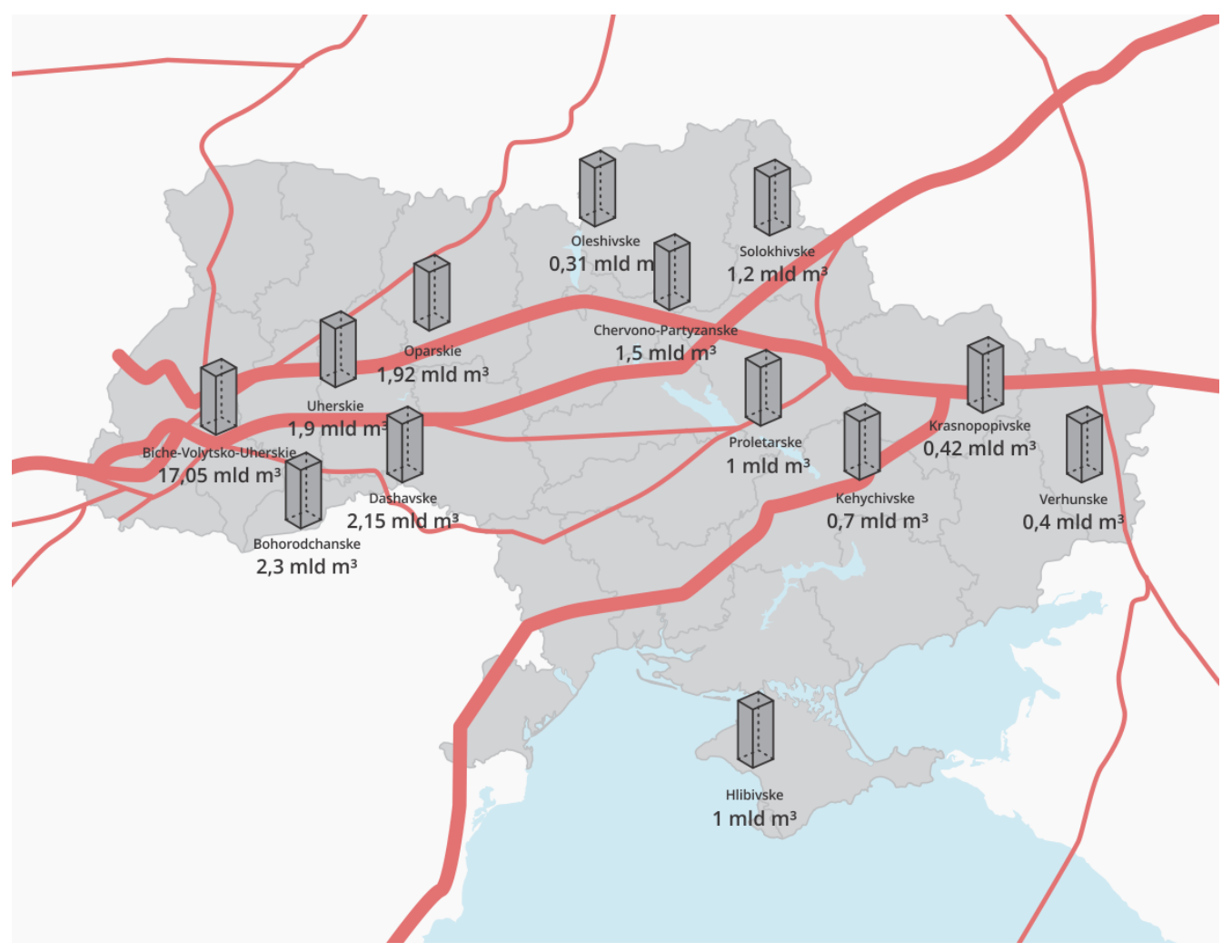

Map 1. Location of underground gas storage in Ukraine Source: own study based on Naftohaz

Mapa 1. Lokalizacja podziemnych magazynów gazu na Ukrainie 


\section{Strategic goals of energy policy of Ukraine and Russia}

The research analysis of the strategic goals of Ukraine and Russia should be performed with reference to the geopolitical context and with consideration of historical issues. This leads to the conclusion that the Russian Federation perceives the territory of Ukraine as the zone of its geopolitical influences and opposes any political activities that would make Ukraine closer to the structures of Western European organizations, such as the European Union and the North Atlantic Treaty Organization. Using different society-connecting channels allows the Russian Federation to reach Ukrainian interest groups represented by oligarchs, who - upon receiving profitable business proposals an - exert influence on Ukrainian politicians in line with Russian interest. Russians support specific political candidates in order to achieve certain political goals in the long run (Paniuszkin and Zygar 2008; Matuszak 2012)*. In the years 1991-2004, many Ukrainian oligarchs became rich thanks to activity in the gas industry. Thus, there is a visible extra plane of complex interdependence between oligarchs from Ukraine and the Russian Federation. The strategic goals of Ukraine are not always in agreement with the business goals of the Ukrainian oligarchs, which creates an additional space for diplomatic activity of Russia.

However, referring to strategic goals, we can see that from the perspective of the Russian Federation the short-term goal is to achieve an agreement guaranteeing the maintenance of a natural gas transmission capacity through the territory of Ukraine after December 31, 2019. A new transit contract could be a short-term one (until 2022) and could be concluded for the transfer of a much smaller amount of natural gas than at present (approx. $60 \mathrm{bcm}$ ). From a medium-term perspective, Russia will strive to build and achieve the full capacity of Nord Stream II (55 bcm) and to complete Turkish Stream. In the long-term perspective, the Russian Federation will want to stop using Ukrainian gas pipelines to transit gas to Europe. Furthermore, Russia will attempt to control the transfer of natural gas from Central Asia to Europe or, if there is some competition, to block it. This would produce bilateral asymmetric relationships allowing more severe political actions against Ukraine.

On the other hand, there is the perspective of Ukraine, which is facing a unique opportunity to sign a contract for the transit of Russian natural gas to Europe and Turkey in the situation of no alternative via Russia. The short-term goal is to sign the transit contract involving the proper

* The Kremlin decision-makers in the person of Viktor Yanukovych looked for an ideal partner for gas transactions even before the presidential elections in 2004, when they were sure that this candidate, by winning, would lead to the rapid signing of contracts with the Russian Gazprom. Gazprom supported Viktor Yanukovych in the 2004 presidential election. This Ukrainian oligarch was Leonid Kuchma's "man" and very often played in Moscow, and visited President Vladimir Putin's residence in Novoogariev near Moscow for his birthday. Three months before the 2004 elections, Gazprom and Naftogaz signed gas supply agreements to eliminate independent intermediaries from trading in raw materials and to entrust the matter to Gazprom's subsidiary company RosUkrEnergo. Eventually, Victor Yushchenko won the elections in December 2004, and on January 1, 2005, as a result of the "repair" of the Turkmenistan gas pipeline, Gazprom interrupted the supply of natural gas, which was resumed after the increase in the price of the gas. It is worth noting that Dmitri Firtash (RosUkrenergo, EuralTransGas), who had good relations with Leonid Kuchma and Viktor Yanukovych, was involved in gas transactions between Russia and Ukraine. 
transit tariff, reservation of transmission capacity, and data exchange (Energetyka24 2018). The medium-term goal is to ensure that Gazprom will carry out the Tribunal's decision. Apart from financial claims, it is even more important to allow the transit of gas from Central Asia via Ukrainian gas pipelines. The long-term goal for Ukraine is to maintain the status of the transit country for Russian natural gas supplies to Europe. However, the key issue is the amount of the transferred gas. It is in Ukraine's interest to transfer as much as possible (at least $60 \mathrm{bcm}$ a year), since this directly translates into budget revenues. It seems that the results of the parliamentary election in Ukraine in 2019 will have a significant influence on the achievement of strategic goals of both countries. The Russian Federation supported candidates with the pro-Russian attitude and those willing to agree to Russian conditions in terms of disputable gas issues. During the election time, internal conflicts in Ukraine may aggravate, and after the election, decentralization forces in different political circles lobbied by groups of oligarchs will even intensify. It is also possible that another gas crisis will take place at the end of 2019, which could be used by Russia as an argument for the construction of new infrastructure bypassing Ukraine (Kost 2018).

\section{Conclusion}

Regarding the research questions posed in the article and drawing conclusions from the research analysis, we can clearly see the energy interdependence between Ukraine and the Russian Federation. However, both countries have an active policy of diversification of import or export, respectively. Ukraine has ceased to import gas directly from Russia, and Russia has built Nord Stream and is building more gas pipelines in order to limit the transit via Ukrainian pipelines.

In the following years, the nature of complex energy interdependence between Ukraine and the Russian Federation will be affected by many factors. Firstly, Ukraine has its own resources of natural gas as well as the potential of shale gas, and increasing the national extraction of gas will lead to a directly proportional reduction in import. The same effect would be achieved by reducing the consumption of natural gas in some sectors of the economy in favor of the development of renewable energy (Child et al. 2017). Secondly, the policy of diversification of natural sources and directions of natural gas supplies to Ukraine will be continued, but as a result of the decision of the Arbitration Tribunal in Stockholm, the country will be obliged to purchase $4 \mathrm{bcm}$ of natural gas directly from the Russian Federation. Perhaps when negotiating the extension of the transit contract, Russia will try to ensure a larger amount of gas supply to Ukraine. The results of the parliamentary election in 2019 will be crucial, because they may give Russia additional opportunities to influence the decision-making processes in Ukraine. Thirdly, the speed of the construction of the Nord Stream II gas pipeline will also be important, as it is expected to provide an additional $55 \mathrm{bcm}$ of natural gas via a direct sea connection between the Russian Federation and the Federal Republic of Germany. From the point of view of commercial energy cooperation, the cheapest route of natural gas supply to Europe after 2019 would still be the 
Ukrainian transmission gas pipelines. Some analytical and research centers in Germany argue the construction of Nord Stream II is pointless, but work on the project is being continued for geopolitical reasons (Neumann et al. 2018). In addition, the Russian Federation is building the Turkish Stream gas pipeline. Fourthly, with consideration of Gazprom's contractual obligations to European countries and the transmission capacity of the existing network of transmission gas pipelines in different countries, the total discontinuation of transfer through Ukrainian gas pipelines is rather improbable, yet the reduction of their use is more and more real. In 2017, Gazprom supplied $193 \mathrm{bcm}$ of natural gas to Europe (the largest amount, $53.4 \mathrm{bcm}$, to Germany) (Malinowski 2018). If some of the factors described above do occur, they will contribute to changing the system of mutual energy interdependences. In the case the Russian Federation gets the advantage, in the theoretical model this will mean greater asymmetry, which could lead to the risk of increasing the possibilities of more severe political and economic Russian interventions in Ukraine. The provisions and conditions of the transit contract concluded after 2019 will be of strategic importance for mutual political relations. Even now, the future contract is clearly the object of negotiation efforts, and apart from the two sides, the largest EU countries also play an active role and the final arrangements may be affected by the decisions of the Arbitration Tribunal in Stockholm. Ukraine's strategic goal should be to negotiate the longest possible transit contract with Russia and to move the points of reception of Russian natural gas by EU partners from the Ukrainian-EU border to the Russian-Ukrainian border (Kardaś and Iwański 2018). Ukraine should use its underground storage facilities to attract Western European companies to conclude contracts for the storage of gas. It is in the interest of Ukraine and the EU to enforce EU law in terms of the establishment of the transmission tariff. Let us imagine a scenario in which Nord Stream II is built but the transmission tariff at the Ukrainian pipelines is still more attractive and competitive. The complex energy interdependence will enter a new phase of asymmetry between Ukraine and Russia, and the dominant position will be taken by the country which displays a greater determination and efficiency in the achievement of its political goals.

\section{References}

ASCARI, S. 2011. An American Model for the EU Gas Market? EUI Working Paper RSCAS No. 39, Robert Schuman Centre for Advanced Studies at Florence School of Regulation.

BetTZÜGE, M.O. and Lochner, S. 2009, The Russian-Ukrainian Gas Conflict in January 2009 - a Model-Based Analysis (Der russisch-ukrainische Gaskonflikt im Januar 2009 - eine modellgestützte Analyse). [In:] Energy industry daily questions (Energiewirtschaftliche Tagesfragen) Vol. 59(7), pp. 26-30 (in German).

BiznesAlert 2018. Ukrainian gas storage facilities are tempting foreign companies. New contracts have been signed (Ukrainskie magazyny gazu kusza zagraniczne spótki. Podpisano nowe umowy). [Online] http://biznesalert.pl/ukrainskie-magazyny-gazu-umowa-trafigura-mnd/ [Accessed: 2018-08-25] (in Polish).

CARR, E.H. 2001. The Twenty Years' Crisis: An Introduction to the Study of International Relations. Basingstoke: Palgrave. 
CHILD, M. et al. 2017. The role of storage technologies for the transition to a $100 \%$ renewable energy system in Ukraine. Energy Procedia No. 135, pp. 410-423.

Energetyka24 2018. Ukraine has revealed what kind of gas transit proposal it will present to Gazprom (Ukraina ujawnita jaka propozycje dotyczaca tranzytu gazu przedstawi Gazpromowi). [Online] https://www.energetyka24.com/ukraina-ujawnila-jaka-propozycje-dotyczaca-tranzytu-gazu-przedstawi-gazpromowi [Accessed: 2018-07-16] (in Polish).

Energy Charter Secretariat 2010. The role of underground gas storage for security of supply and gas markets. Occasional Paper, Energy Charter Secretariat, Brussels.

FEDOROV, Y. 2013. Continuity and change in Russia's policy toward Central and Eastern Europe. Communist and Post-Communist Studies Vol. 46, pp. 315-326.

GraBAU, M. 2018. The change in European gas foreign policy as a result of the Ukrainian crisis (Der Wandel der europäischen Erdgasaußenpolitik infolge der Ukraine-Krise). Gas Games, Springer 2018. (in German).

GoldTHAU, A. and BOERSMA, T. 2014. Ukraine-Russia crisis: Implications for energy markets and scholarship. Energy Research \& Social Science Vol. 3, pp. 13-15.

KARDAŚ, S. and IWAŃSKI, T. 2018. From vassalisation to emancipation. Ukrainian-Russian gas co-operation has been revised. [Online] https://www.osw.waw.pl/en/publikacje/osw-commentary/2018-03-07/ vassalisation-to-emancipation-ukrainian-russian-gas-co [Accessed: 2018-07-10].

KARDAŚ, S. and KONOŃCZUK, W. 2018. Naftogaz's victory over Gazprom: The Arbitral Tribunal's award on the transit contract. [Online] https://www.osw.waw.pl/en/publikacje/analyses/2018-03-07/naftohazS-victory-over-gazprom-arbitral-tribunals-award-transit [Accessed: 2018-07-23].

KARDAŚ, S. and MATUSZAK, S. 2018. Start of execution of Gazprom's debt to Naftogaz (Poczatek egzekucji dlugu Gazpromu wobec Naftogazu). [Online] https://www.osw.waw.pl/pl/publikacje/analizy/2018-06-13/poczatek-egzekucji-dlugu-gazpromu-wobec-naftohazu [Accessed: 2018-08-21] (in Polish).

Keohane, R.O. and Nye, J. 1977. Power and Interdependence: World Politics in Transition. Boston.

Kost, P. 2018. It's about gas transit to Europe. Ukraine keeps Russia in check? (Gra o tranzyt gazu do Europy. Ukraina trzyma Rosję w szachu?). [Online] https://www.energetyka24.com/gra-o-tranzyt-gazudo-europy-ukraina-trzyma-rosje-w-szachu [Accessed: 2018-07-05] (in Polish).

LUTTWAK, E. 1990. From geopolitics to geoeconomics. Logic of conflict, grammar of comerce. The National Interest No. 20, 17 pp.

ŁoŚ-NowAK, T. 2000. International Relations. Theories - schemes - participants (Stosunki międzynarodowe. Teorie - systemy - uczestnicy). University of Wrocław (in Polish).

MALINOWSKI, D. 2019. Gazprom supplied almost 200 billion $\mathrm{m}^{3}$ of gas to Europe (Gazprom dostarczyl do Europy prawie $200 \mathrm{mld} \mathrm{m}^{3} \mathrm{gazu}$ ). [Online] https://gazownictwo.wnp.pl/gazprom-dostarczyl-do-europy -prawie-200-mld-m3-gazu,314432_1_0_0.html [Accessed: 2019-08-27] (in Polish).

MATUSZAK, S. 2012. Oligarchic democracy. Influence of business groups on Ukrainian politics (Demokracja oligarchiczna. Wpływ grup biznesowych na ukraińska politykę). Warsaw: Ośrodek Studiów Wschodnich, $54 \mathrm{pp}$.

Morgenthau, H. 1956. Politics Among Nations: The Struggle for Power and Peace. New York.

Naftogaz 2017. Naftogaz wins the gas sales arbitration case against Gazprom on all issues in dispute. [Online] http://www.naftogaz.com/www/3/nakweben.nsf/0/1CBBBA42E2336FDCC22581FE0042E27F?OpenDocument\&year=2017\&month=12\&nt=News\& [Accessed: 2018-03-18].

Naftogaz 2018. Ukraine imported $14.1 \mathrm{bcm}$ of gas from Europe in 2017 (+27\%). [Online] https://naftogaz-europe.com/article/en/ukraineimported141bcmofgasfromeuropein2017 [Accessed: 2018-08-24].

NeUmanN, A. et al. 2018. Natural gas supply: no need for another Baltic Sea pipeline. DIW Weekly Report, No. 27, DIW, pp. 242-248 
NiEBUHR, R. 1960. Moral Man and Immoral Society: A Study in Ethics and Politics. Washington: Library of Theological Ethics.

PANIUSZKIN, W. and ZYGAR M. 2008. Gazprom Russian Weapon (Gazprom rosyjska broń). Warsaw: W.A.B., pp. 181-205.

RANA, W. 2015. Theory of Complex Interdependence: A Comparative Analysis of Realist and Neoliberal Thoughts. International Journal of Business and Social Science Vol. 6, No. 2, pp. 290-297.

Roson, R. and Hubert, F. 2014. Bargaining Power and Value Sharing in Distribution Networks: A Cooperative Game Theory Approach. Centre for Research on Energy and Environmental Economics and Policy at Bocconi University.

RUSZEL, M. 2014. Energy security of Poland: theoretical and practical aspects (Bezpieczeństwo energetyczne Polski. Wymiar teoretyczny i praktyczny). Warsaw: Rambler, pp. 16-183 (in Polish).

RUSZEL, M. 2015. The influence of the Russian-Ukrainian gas crises on the EU energy policy - theoretical approach (Wpływ rosyjsko-ukraińskich kryzysów gazowych na politykę energetyczna UE-ujęcie teoretyczne). Przeglad Politologiczny No. 2/2015, Poznań: WNPiD UAM, pp. 49-58 (in Polish).

STĘPIŃSKI, P. 2018. Talks about gas transit through Ukraine without a breakthrough (Rozmowy o tranzycie gazu przez Ukrainę bez przełomu). [Online] http://biznesalert.pl/ke-ukraina-rosja-rozmowy-gaz/ [Accessed: 2018-07-18] (in Polish).

SZEPTYCKI, A. 2008. Relations between the Russian Federation and Ukraine in the gas sector (Stosunki pomiędzy Federacja Rosyjska i Ukraina w sektorze gazowym). [In:] Wyciszkiewicz, E. ed. Geopolitics of pipelines. Energy interdependence and interstate relations in the post-Soviet area (Geopolityka rurociagów. Wspótzależność energetyczna a stosunki międzypaństwowe na obszarze postpowieckim), Warsaw: Polski Instytut Spraw Międzynarodowych, pp. 103 (in Polish).

Ukrtransgaz 2018. Ukrtransgaz Today. [Online] http://utg.ua/en/utg/company/ukrtransgaz-today.html [Accessed: 2018-08-06].

WALTZ, K. 1993, The emerging structure of international politics. "International Security" No. 2, pp. 52-67.

Yergin, D. 2012. The Quest. Energy, security and the remaking of the modern world. Penguin Books, pp. 341.

ZANIEWICZ, M. 2018. Poland is third largest gas supplier to Ukraine (Polska trzecim dostawca gazu na Ukraine). [Online] https://www.energetyka24.com/polska-jest-trzecim-dostawca-gazu-na-ukraine [Accessed: 2018-04-24] (in Polish). 


\section{Dostawy gazu ziemnego jako instrument geopolityczny pomiędzy Federacją Rosyjską a Ukrainą}

\section{Streszczenie}

Dostawy gazu ziemnego są wykorzystywane przez Federację Rosyjską jako instrument polityczny w geopolitycznej rywalizacji z Ukrainą. Skuteczność rosyjskiej strategii wobec Ukrainy wynika z faktu, że władza polityczna w Kijowie sprawowana jest również przez prorosyjskich polityków i wspierana przez ukraińskich oligarchów. Obydwa państwa pozostają względem siebie w relacji współzależności energetycznej poprzez istniejącą infrastrukturę gazową oraz kontrakty długoterminowe, gdyż Ukraina gwarantuje Federacji Rosyjskiej tranzyt gazu ziemnego poprzez swój system gazociągów przesyłowych do Europy, zaś Rosja płaci za tranzyt oraz dostarczała zakontraktowaną ilość gazu na Ukrainę. W 2016 roku po raz pierwszy Ukraina nie importowała gazu ziemnego bezpośrednio z Federacji Rosyjskiej. W tym artykule podjęto próbę uzyskania odpowiedzi na pytanie badawcze, czy Ukraina rzeczywiście dąży do dywersyfikacji dostaw gazu ziemnego. W jakiej części ta polityka staje się instrumentem politycznym Ukrainy wobec Rosji i jaki jest jej prawdziwy cel polityczny? Zwłaszcza w kontekście kończącego się w 2019 r. kontraktu gazowego między oboma państwami. Jaką rolę w walce geopolitycznej odegrają podziemne magazyny gazu? Pomimo Nord Stream II Federacja Rosyjska nadal potrzebuje ukraińskich rurociągów do wypełnienia zobowiązań umownych w zakresie dostaw gazu do Europy. Jakie są strategiczne cele polityki energetycznej Ukrainy i Rosji? W artykule zastosowano teorię geopolityczną, a także podejście geoekonomiczne. Ponadto wykorzystano analizę metody czynnikowej oraz analizę decyzyjną. Metoda analizy politycznej i technika prognozowania znajdują zastosowanie w wymiarze teoretycznym oraz praktycznym.

SŁoWA KLUCZOWE: gaz ziemny, gazociągi, geopolityka, Ukraina, Federacja Rosyjska 
